JURNAL CEMERLANG: Pengabdian pada Masyarakat ISSN 2654-4741

Vol. 1, No. 1, 2018, $71-89$

DOI: https://doi.org/10.31540/jpm.v1i1.160

\title{
PELATIHAN PEMANFAATAN MEDIA SOSIAL EDMODO SEBAGAI MEDIA PENDUKUNG PEMBELAJARAN BAGI GURU DI SMP TAMANSISWA PALEMBANG
}

Rika Firma Yenni, Malalina

Universitas Tamansiswa Palembang, Indonesia

\begin{abstract}
ABSTRAK
Media sosial yang mempunyai banyak manfaat dalam pembelajaran adalah Edmodo. Edmodo adalah media sosial yang berdasarkan pada lingkungan sekolah (school based environment). Edmodo merupakan media sosial yang bisa dimanfaatkan oleh guru, siswa dan orang tua siswadi kelas pada suatu sekolah. Edmodo memberikan cara yang mudah untuk berhubungan antara guru dan siswa, maupun antara guru dan orang tua siswa sehingga menciptakan interaksi yang kuat dan memudahkan dalam berkomunikasi tanpa harus bertatapan langsung. Tujuan pelatihan ini adalah menyampaikan pengetahuan bagaimana menggunakan Edmodo dan melatih guru menggunakan Edmodo dalam proses pembelajaran. Masalah yang ditemui dalam pelatihan ini adalah guru belum memanfaatkan media sosial Edmodo dalam proses belajar mengajar. Metode yang digunakan adalah ceramah dan diskusi, demonstrasi, serta bimbingan dan praktek. Dengan simpulan peserta sudah bisa membuat akun Edmodo dan menggunakannya dalam proses pembelajaran di sekolah, serta adanya media sosialEdmodo sebagai salah satu media pembelajaran pada setiap bidang ilmu yang dimiliki oleh guru dalam proses pembelajaran di SMP Tamansiswa Palembang.
\end{abstract}

KEYWORDS

Media Sosial, Edmodo, Computer Network, Internet, Media Pembelajaran
ARTICLE HISTORY

Received 23 November 2018

Revised 14 December 2018

Accepted 19 December 2018

CORRESPONDENCE Rika Firma Yenni@ rika_firma@unitaspalembang.ac.id 


\section{JURNAL CEMERLANG: Pengabdian pada Masyarakat}

ISSN 2654-4741

Vol. 1, No. 1, 2018, $71-89$

DOI: https://doi.org/10.31540/jpm.v1i1.160

\section{PENDAHULUAN}

Pemanfaatan computer network atau yang lebih dikenal dengan internet di era milenial 4.0 ini sudah semakin berkembang. Selain sebagai alat komunikasi, computer network juga dimanfaatkan sebagai alat untuk menemukan berbagai informasi dan pengetahuan disegala aspek kehidupan. Computer network (jaringan komputer) merupakan sebuah sistem/kesatuan yang terdiri atas beberapa komputer yang sengaja didesain untuk dapat berbagi sumber daya, berkomunikasi pesan instan dan dapat mengakses informasi web, informasi dan data bergerak melalui kabel-kabel atau tanpa kabel (nirkabel), sehingga memungkinkan seorang pengguna jaringan komputer dapat saling bertukar informasi, dokumen, dan data (seperti web), mencetak pada printer yang sama dan bersamaan menggunakan hardware dan sotware yang terhubung dengan jaringan (Supriatna, 2013).Sedangkan menurut Williams (Munir, 2010), internet dapat dikatakan sebagai "a large collection of computers in networks that are tied together so that many users can share their vast resources".Jadi secara sederhana internet merupakan kumpulan dari jutaan komputer diberbagai belahan dunia yang terkoneksi antara yang satu dengan yang lain.

Media sosial atau yang sering juga disebut sebagai jaringan sosial adalah struktur sosial yang terdiri dari elemen-elemen individual atau organisasi (Tammimudin \& Ekawati, 2011). Menurut Tea (2014) media social (social media) adalah saluran atau sarana pergaulan social secara online di dunia maya (internet), para pengguna (user) media sosial berkomunikasi, berinteraksi, saling kirim pesan, dan saling berbagi (sharing), dan membangun jaringan (networking). Denganmedia sosial para penggunanya bisa berpartisipasi, berbagi, dan menciptakan sesuatu dengan mudah dan cepat. Adanya istilah media sosial tidak lepas dari dampak globalisasi dan perkembangan zaman. Dahuluorang saling mengirimkan kabar melalui sepucuk surat,yang manamembutuhkan waktu yang cukup lama untuk proses pengirimannya. Tetapi sekarang seakan tidak ada jarak pembatas antara pengirim dan penerima dimanapun mereka berada, bahkan dipenghujung dunia sekalipun. Beragam layanantelahdisediakan oleh media 


\section{JURNAL CEMERLANG: Pengabdian pada Masyarakat}

ISSN 2654-4741

Vol. 1, No. 1, 2018, $71-89$

DOI: https://doi.org/10.31540/jpm.v1i1.160

sosialseperti_Blog, Facebook, Twitter, Yahoo Messenger dan masih banyak lagi yang bisa membuat kita menjelajahi dunia melalui media sosial.

Salah satu contoh media sosialseperti situs facebook sangat sering digunakan sekarang ini, mulai dari kalangan dewasa, remaja, bahkan anak-anak. Menurut Septania (2018), per-Januari 2018 pengguna Facebook di Indonesia adalah yang terbanyak keempat setelah Brazil yakni mencapai 130 juta pengguna. Hal ini sesuai dengan laporan riset We are Social dan Hootsuite yang dirilis di Linkedin pada 2 Maret 2018. Tak hanya negara, data juga menyebutkan bahwa Bekasi dan Jakarta merupakan dua kota dengan jumlah pengguna Facebook paling aktif (Reza, 2017). Kota Bekasi menduduki urutan ketiga dengan jumlah pengguna mencapai 18 juta pengguna, sedangkan Jakarta berada di urutan keempat dengan jumlah 16 juta pengguna. Dari sekian banyak pengguna Facebook di Indonesia, tentu saja sebagian besar penggunanya berasal dari kalangan pelajar dan guru. Tren pemanfaatan media sosial ini dapat menjadi peluang, serta memudahkan guru dalam proses pembelajaran.

Sekarang ini, para pelajar baik siswa maupun mahasiswa sudah banyak yang menggunakan computer network atau internet dalam proses pembelajaran. Dulunya mereka hanya menggunakan buku sebagai sumber belajar, tetapi sekarang berbagai materi pelajaran bisa mereka jumpai pada media sosial, sehingga mereka tidak hanya membaca tulisan yang ada pada buku pelajaran, tetapi juga menemukan beragam informasi yang ada pada media sosial. Berbagai media sosial memberikan kemudahan dalam menemukan materi pelajaran berbentuk file seperti Flash, Powerpoint, dll yang bisa dimanfaatkan sebagai alat dalam proses pembelajaran.

Menurut Rustian (2012), media sosial dapat dikelompokkan menjadi beberapa bagian besar yaitu :

- Social Networks, media sosial untuk bersosialisasi dan berinteraksi (facebook,edmodo,myspace, hi5, Linked in, bebo, dll)

- Discuss, media sosial yang memfasilitasi sekelompok orang untuk melakukan obrolan dan diskusi (google talk, yahoo! M, skype, phorum, dll) 


\section{JURNAL CEMERLANG: Pengabdian pada Masyarakat}

ISSN 2654-4741

Vol. 1, No. 1, 2018, $71-89$

DOI: https://doi.org/10.31540/jpm.v1i1.160

- Share, media sosial yang memfasilitasi kita untuk saling berbagi file, video, music, dll (youtube, slideshare, feedback, flickr, crowdstorm, dll)

- Publish, (wordpredss, wikipedia, blog, wikia, digg, dll)

- Social game, media sosial berupa game yang dapat dilakukan atau dimainkan bersama-sama (koongregate, doof, pogo, cafe.com, dll)

- $M M O$ (kartrider, warcraft, neopets, conan, dll)

- Virtual worlds (habbo, imvu, starday, dll)

- Livecast (y! Live, blog tv, justin tv, listream tv, livecastr, dll)

- Livestream (socializr, froendsfreed, socialthings!, dll)

- Micro blog (twitter, plurk, pownce, twirxr, plazes, tweetpeek, dll)

Sekarang ini, media sosial yang mempunyai berbagai karakteristik untuk media pembelajaran adalah Edmodo. Edmodo adalah media sosial yang berdasarkan pada lingkungan sekolah (school based environment). Dikembangkan oleh Nicolas Borgdan Jeff O'Hara pada tahun 2008. Edmodo merupakan media sosial yang bisa dimanfaatkan oleh guru, siswa dan orang tua siswa di kelas pada suatu sekolah. Edmodo memberikan cara yang mudah untuk berhubungan antara guru dan siswa, maupun antara guru dan orang tua siswa sehingga menciptakan interaksi yang kuat dan memudahkan dalam berkomunikasi tanpa harus bertatapan langsung. Seperti halnya media sosial yang lain, Edmodo bisa diakses secara gratis pada situs (https://www.edmodo.com). Edmodo menjadi salah satu jaringan sosial yang paling cepat berkembang di tahun 2011 awal, terbukti dengan adanya sekitar 1 juta pengguna di dalamnya. Hanya beberapa bulan kemudian, pengguna bertambah menjadi 7 juta orang dan akhirnya pada tahun 2015, terdapat 50 juta pengguna Edmodo yang berasal dari berbagai belahan dunia (Zakaria, 2018).

Menurut Pitoy (2012), Edmodo merupakan sebuah platform social network bagi guru dan siswa untuk berbagi ide, file, agenda kegiatan dan penugasan. Edmodo dibuat untuk mewujudkan interaksi dan komunikasi antara guru dan siswa yang lebih cepat. Siswa bisa berkomunikasi langsung dengan guru, bisa melakukan tanya jawab dan bertukar pikiran dengan siswa lain, mengirimkan tugas, serta Edmodo juga dapat diakses oleh orang tua siswa. Guru juga bisa https://ojs.stkippgri-lubuklinggau.ac.id/index.php/JPM 


\section{JURNAL CEMERLANG: Pengabdian pada Masyarakat}

ISSN 2654-4741

Vol. 1, No. 1, 2018, $71-89$

DOI: https://doi.org/10.31540/jpm.v1i1.160

berkomunikasi langsung dengan orang tua siswa. Dengan memanfaatkan Edmodo, guru bisa menambahkan materi pelajaran, memberi tugas atau latihan, membagikan catatan, menyampaikan informasi berupa pengumuman, memberikan quiz, dan memberikan nilai, serta bagi orang tua siswa juga bisa memonitoring nilai anak mereka dengan menggunakan Edmodo. Menurut Kurniasih (2016), Edmodo memiliki beberapa manfaat yaitu:

- Mempermudah komunikasi guru dan siswa, serta orang tua

- Guru dapat memberikan materi secara langsung ataupun terjadwal

- Guru akan mendapatkan daftar siswa yang mengerjakan tugas dan yang tidak serta daftar nilai secara otomatis

- Guru dapat memberikan file maupun link kepada siswa untuk dipelajari

- Guru dapat memberikan quiz, polling, penilaian, daftar nilai, award, dls

- Siswa dapat mengerjakan tugas kapan pun dan dimana saja

- Siswa dapat melihat nilai dan hasil dari tugas

- Orang tua dapat melihat langsung pembelajaran dan hasil kerja siswa secara langsung

Di Indonesia, belum banyak yang menggunakan media sosial Edmodo dalam pembelajaran, padahal media sosial ini bisa memberikan manfaat untuk meningkatkan dan mengembangkan media ajar bagi guru di sekolah. Apalagi di SMP Tamansiswa Palembang belum pernah menggunakan media sosial ini, bahkan ada sebagian guru yang belum mengetahui apa itu Edmodo. Padahal ratarata guru dan siswa menggunakan smartphone setiap harinya. Jadi dengan Edmodo, smartphone juga bisa dimanfaatkan dalam proses pembelajaran karena guru dan siswa bisa mengakses Edmodo melalui smartphone. Untuk penulis mengadakan kegiatan pengabdian "Pelatihan Pemanfaatan Media Sosial Edmodo sebagai Media Pendukung Pembelajaran bagi Guru di SMP Tamansiswa Palembang". Tujuan pelatihan ini adalah memberikan pengetahuan bagaimana menggunakan Edmodo dan melatih guru menggunakan Edmodo dalam proses pembelajaran. 


\section{JURNAL CEMERLANG: Pengabdian pada Masyarakat}

\section{ISSN 2654-4741}

Vol. 1, No. 1, 2018, $71-89$

DOI: https://doi.org/10.31540/jpm.v1i1.160

\section{MASALAH}

Berdasarkan penjabarantersebut, dapat dirumuskan masalah yang berkaitan dengan kegiatan pengabdian ini yaitu: guru belum memanfaatkan media social Edmodo dalam kegiatan proses pembelajaran. Oleh karena itu diadakan pelatihan bagaimana menggunakan Edmodo sebagai media pendukung pembelajaran bagi guru di SMP Tamansiswa Palembang. Dengan pemanfaatan media social Edmodo akan menjadikan siswa lebih aktif dan semangat dalam belajar.

\section{METODE}

Untuk mengatasi permasalahan dalam pemanfaatan media social Edmodo dalam kegiatan proses pembelajaran maka dilaksanakan pelatihan penggunaan Edmodo di SMP Tamansiswa Palembang. Sasaran kegiatan ini adalah guru SMP Tamansiswa Palembang yang berjumlah20 orang. Adapun yang menjadi instruktur dan narasumber pada pelatihan tersebut adalah penulis dan dibantu oleh seorang teman sejawat yang juga selaku Dosen Program Studi Pendidikan Matematika di Universitas Tamansiswa Palembang.

Metode yang digunakan dalam pengabdian ini adalah :

1. Ceramah dan Diskusi

Digunakan untuk memberikaninformasi dan menyampaikan konsep-konsep penting yang berkaitan dengan media sosial Edmodo serta manfaat menerapkannya dalam pembelajaran agar dimengerti dan dipahami oleh para guru yang mengikuti pelatihan. Dengan alasanjika metode ceramah dikombinasikan dengan gambar/animasi dan tampilan secara langsung seperti pada power point, penulis dapat menyampaikan materi pelatihan secaracepat, dan mudah.

2. Demonstrasi

Digunakan untuk menunjukkan suatu proses kerja yaitu tahap-tahap dan langkah-langkah pengenalan Edmodo serta penerapannya di kelas. Demonstrasi dilakukan oleh seorang dosen di hadapan peserta. 


\section{JURNAL CEMERLANG: Pengabdian pada Masyarakat}

ISSN 2654-4741

Vol. 1, No. 1, 2018, $71-89$

DOI: https://doi.org/10.31540/jpm.v1i1.160

3. Bimbingan dan Praktek

Metode ini digunakan untuk menindaklanjuti dan mematangkan materi yang telah disampaikan. Selama kegiatan peserta akan mendapatkan modul tentang membuat akun Edmodo dan bagaimana menggunakan serta menerapkannya. Sehingga peserta bisa langsung mempraktekkannya.

Adapun tahapan pelaksanaan pengabdian meliputi:

1. Tahap Persiapan

Pada tahap ini yang dilakukan penulis adalah :

a. Menyiapkan berbagai adiministrasi yang diperlukan

b. Koordinasi dengan kepala SMP Tamansiswa Palembang tentang kegiatan pengabdian yang akan dilaksanakan

c. Menyiapkan materi

d. Menyiapkanruangan

e. Menyiapkan alat-alat yang digunakan saat pelatihan

f. Menyiapkan jadwal kegiatan

\section{Tahap Pelaksanaan Kegiatan}

Pada tahap ini kegiatan yang dilakukan penulis adalah :

a. Penyampaian materi tentang Edmodo

b. Pelatihan pembuatan akun Edmodo, penggunaan dan penerapannya dalam pembelajaran

\section{Tahapan Evaluasi}

Pada tahap ini, kegiatan yang dilakukan adalah evaluasi terhadap implementasi kegiatan pelatihan yang telah dilaksanakan.

Kegiatan pengabdian masyarakat ini dilaksanakan pada tanggal 8 September 2018 di SMP Tamansiswa Palembang. Durasi kegiatan pengabdian selama 480 menit (pukul 08.00 - 16.00 WIB) dengan rincian 420 menit (pelatihan) dan 60 menit (istirahat, shalat, dan makan siang). Pelatihan ini melibatkan guru SMP Tamansiswa Palembang. 


\section{JURNAL CEMERLANG: Pengabdian pada Masyarakat ISSN 2654-4741 \\ Vol. 1, No. 1, 2018, $71-89$ \\ DOI: https://doi.org/10.31540/jpm.v1i1.160}

\section{PEMBAHASAN}

Pelaksanaan kegiatan pengabdian kepada masyarakat meliputi tahap persiapan, pelaksanaan kegiatan, dan evaluasi. Pada tahap persiapan yaitu dengan mempersiapkan berbagai hal yang dibutuhkan pada saat dilaksanakannya kegiatan pengabdian. Pada tahap pelaksanaan kegiatan, dilakukan penyampaian materi dan pelatihan Edmodo. Materi yang disampaikan meliputi:

1. Pembuatan akun Edmodo

Seperti halnya media sosial lain, Edmodo bisa diakses secara gratis. Sebelum menggunakan Edmodo, pengguna harus membuat akun seperti berikut ini:

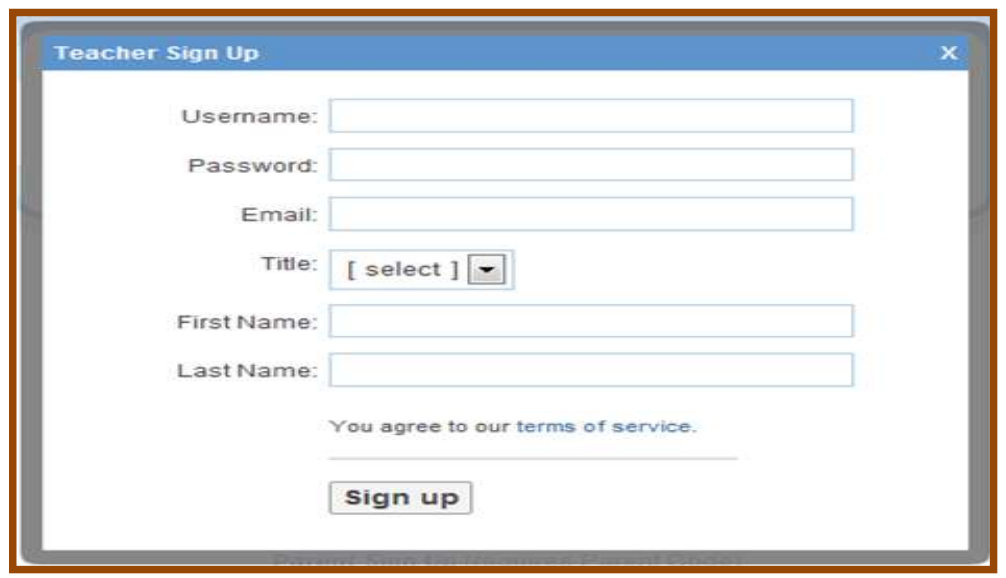

Gambar tersebut adalah pembuatan akun sebagai guru. Setelah registrasi, silahkan cek email untuk melakukan konfirmasi. Guru juga bisa menyunting profil pada akun yang telah dibuat, seperti gambar berikut:

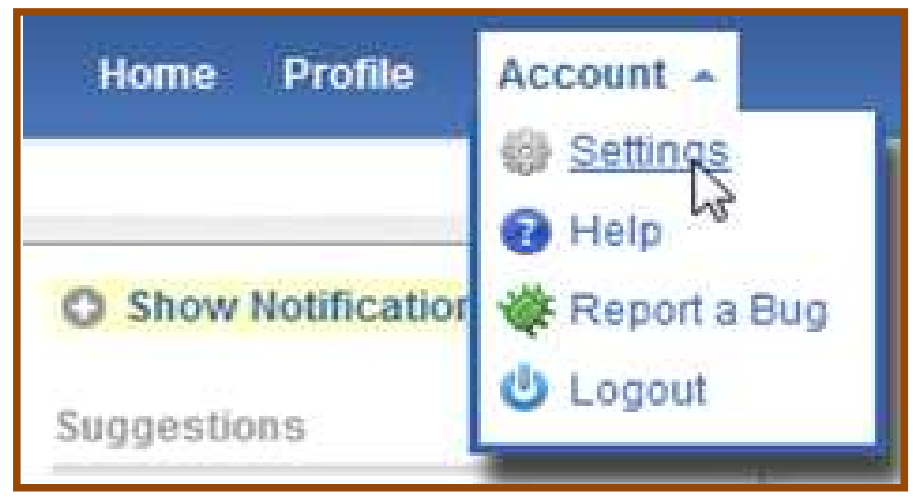

https://ojs.stkippgri-lubuklinggau.ac.id/index.php/JPM 


\section{JURNAL CEMERLANG: Pengabdian pada Masyarakat ISSN 2654-4741 \\ Vol. 1, No. 1, 2018, $71-89$ \\ DOI: https://doi.org/10.31540/jpm.v1i1.160

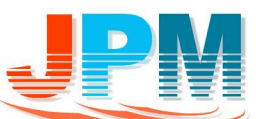

Setelah mempunyai akun sebagai guru, guru juga bisamembuat kelas di Edmodo. Seperti pembelajaran yang berlangsung di sekolah, gurubisa membuat lebih dari satu kelas. Setiap kelas yang dibuat akan memiliki password, sehingga hanya siswa pada kelas kita yang dapat memasuki kelas tersebut. Untuk masing-masing siswa yang tergabung pada setiap kelas, Edmodo juga memberikan kode atau sandi untuk orang tua siswa sehingga mereka bisa memonitoring perkembangan putra-putrinya secara langsung.

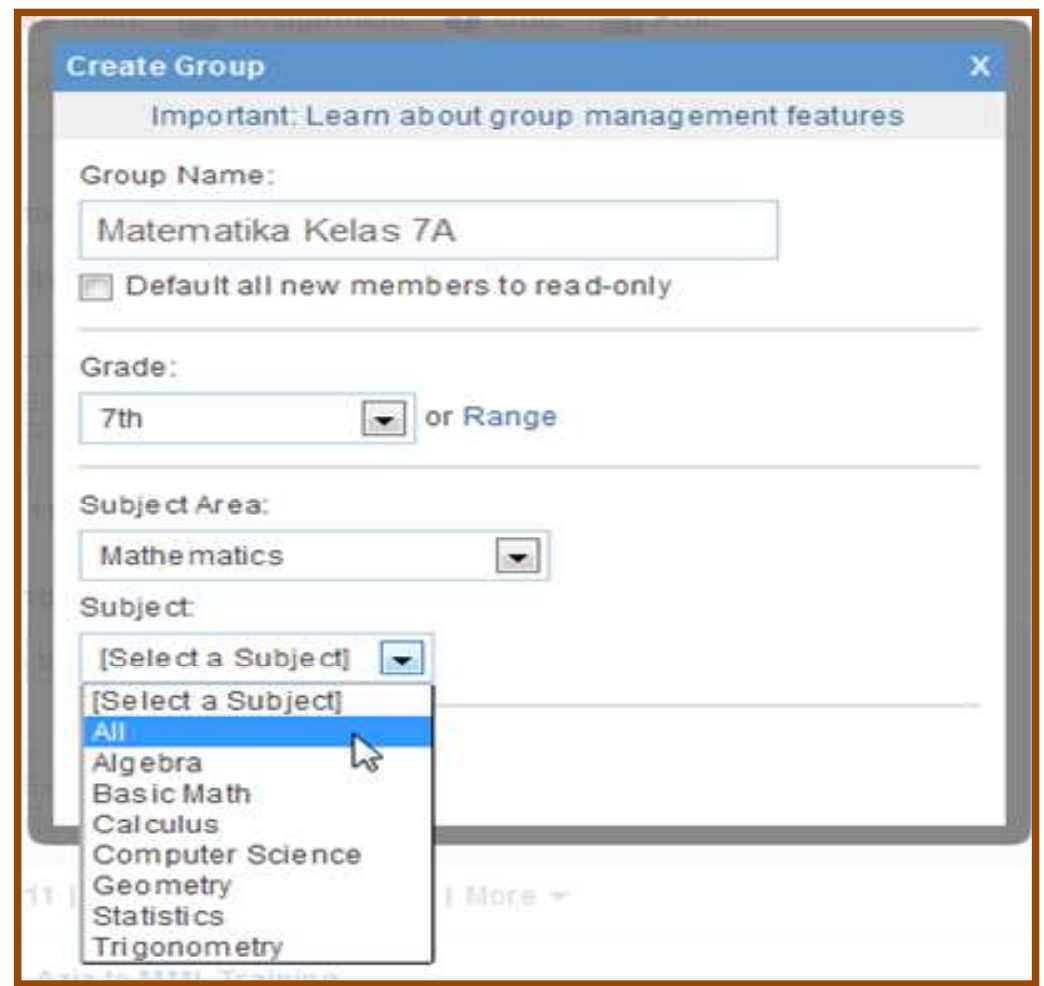

2. Penggunaan dan Penerapan dalam Pembelajaran

Dengan menggunakan Edmodo, guru bisa mengembangkan bahan ajar sehingga dapat menambah minat siswa dalam pembelajaran. Beberapa karakteristikEdmodo yang bisa digunakan dalam kegiatan pembelajaran, yaitu:

a. Memasukkan dan menyusun materi ajar di library

Setelah membuat akun Edmodo dan membuat kelas Edmodo, guru bisa memasukkan materi ajar berupa buku, catatan, modul, LKS dll ke dalam 
JURNAL CEMERLANG: Pengabdian pada Masyarakat ISSN 2654-4741

Vol. 1, No. 1, 2018, $71-89$

DOI: https://doi.org/10.31540/jpm.v1i1.160

akun kelas Edmodo yang telah dibuat. Misalnya guru ingin mengunggah buku elektronik ke dalam librarydi dalam Edmodo.

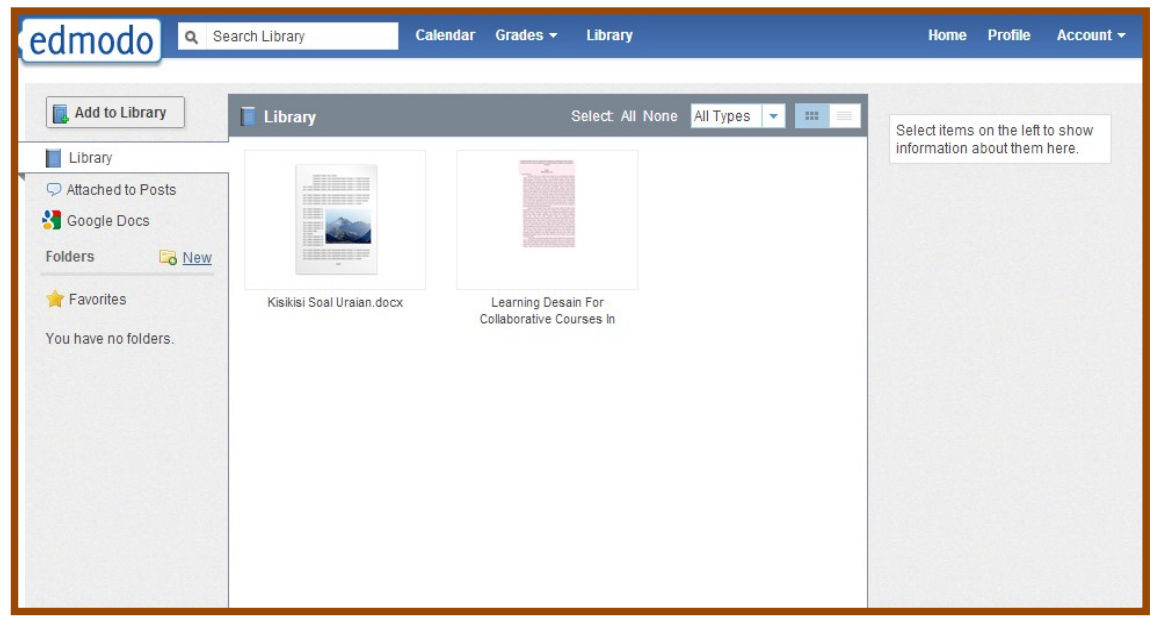

b. Membuat catatan

Catatan (note) pada Edmodo sama dengan yang ada pada facebook.

Dengan Edmodo, guru bisa menambahkan catatan tentang materi pembelajaran yang akan dipelajari. Dapat pula mengunggah video yang menarik tentang pembelajaran, sehingga bisa meningkatkan motivasi dan minat siswa dalam proses belajar mengajar. Perhatikan gambar berikut:

Matematika Kelas X

Filter posts by $\mathrm{F}$ Post:

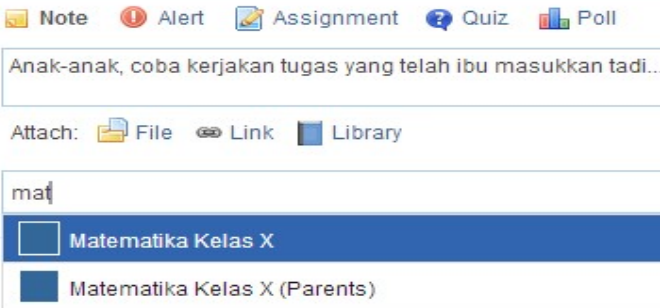

c. Membuat pengumuman

Pengumuman (alert) adalah salah satu jenis catatan (note)yang lebih sederhana, karena tidak mempunyai lampiran berupa file, link ataulibrary. Pada fitur ini, dalam pembelajaran dapat digunakan sebagai 
JURNAL CEMERLANG: Pengabdian pada Masyarakat ISSN 2654-4741

Vol. 1, No. 1, 2018, $71-89$

DOI: https://doi.org/10.31540/jpm.v1i1.160

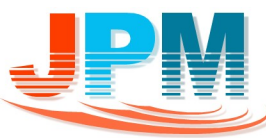

alat penyampaian pengumuman, seperti pengumuman jadwal ujian, pengumuman waktu mengumpulan latihan dan sebagainya.

d. Membuat penugasan

Penugasan adalah salah satu karakteristik yang membedakan Edmodo dengan media sosial lain. Melalui karakteristik ini guru bisa memberikan tugas dan latihan pada siswa dengan memberikan batasan waktu pengumpulannya, serta juga bisa memberi penilaian secara langsung.

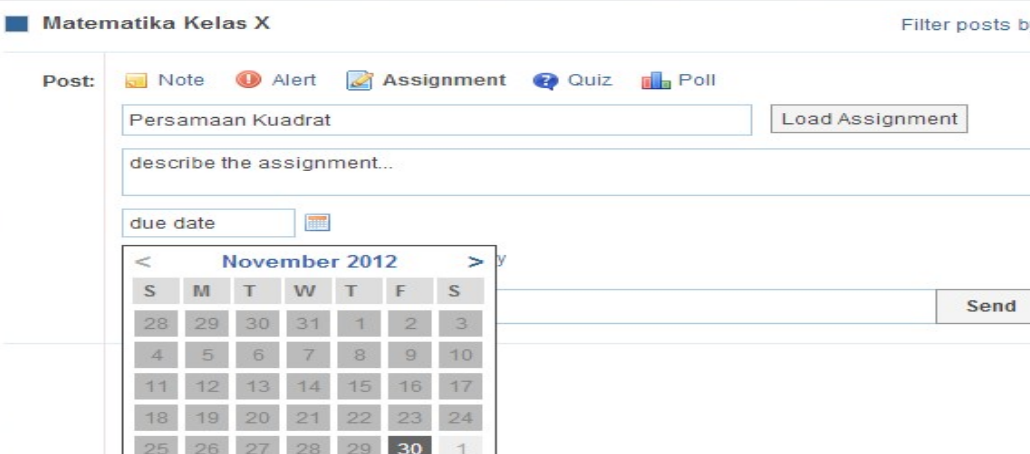

e. Membuat quiz

Pada fitur quiz, guru dapat memilih jenis quiz yang dinginkan misalnya multiple choice, true-false, short answer, dan fill in the blank.

\begin{tabular}{|c|c|c|c|c|c|}
\hline \multicolumn{3}{|c|}{ Q kuis lingkaran } & Time Limit: & 60 & Minutes \\
\hline \multicolumn{6}{|c|}{ Add your first question to start creating a quiz... } \\
\hline \multirow[t]{3}{*}{ Type: } & Multiple Choice $\nabla$ & +Add First Question & \multicolumn{3}{|c|}{ or Load First Question } \\
\hline & Multiple Choice & & & & \\
\hline & $\begin{array}{l}\text { True False } \\
\text { Short Answer } \\
\text { Fill in the blank }\end{array}$ & & & & \\
\hline
\end{tabular}

- Mutiple Choise Quiz

Pada multiple choice quiz ini, telah disediakan kolom untuk pertanyaan dan pilihan jawaban yang memungkinkan. Jumlah pilihan jawaban dapat diatur sesuai dengan kebutuhan.

https://ojs.stkippgri-lubuklinggau.ac.id/index.php/JPM 
JURNAL CEMERLANG: Pengabdian pada Masyarakat ISSN 2654-4741

Vol. 1, No. 1, 2018, $71-89$

DOI: https://doi.org/10.31540/jpm.v1i1.160
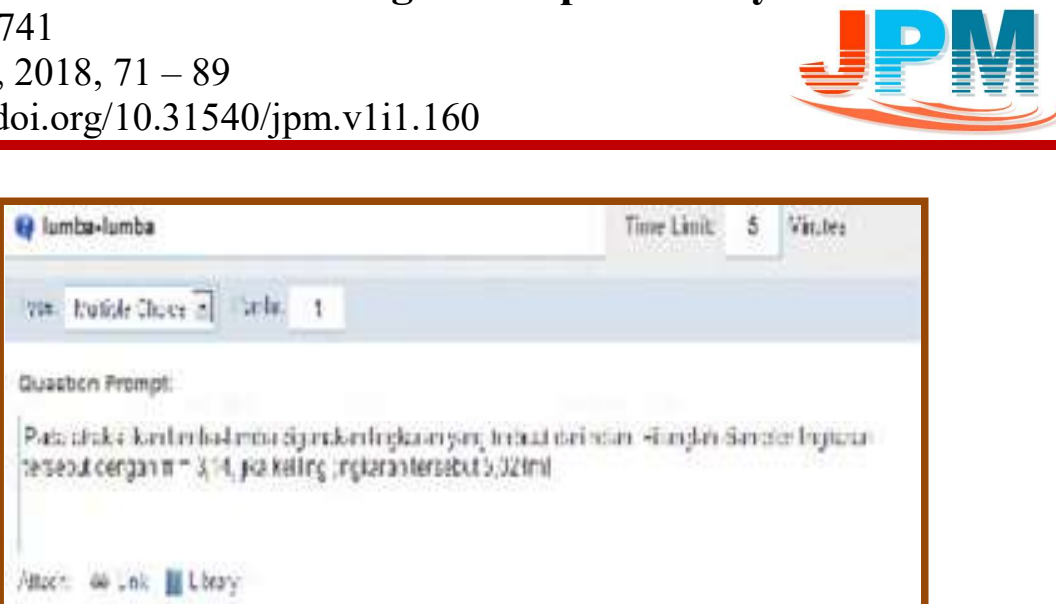

Contoh jawaban multiple choice quiz

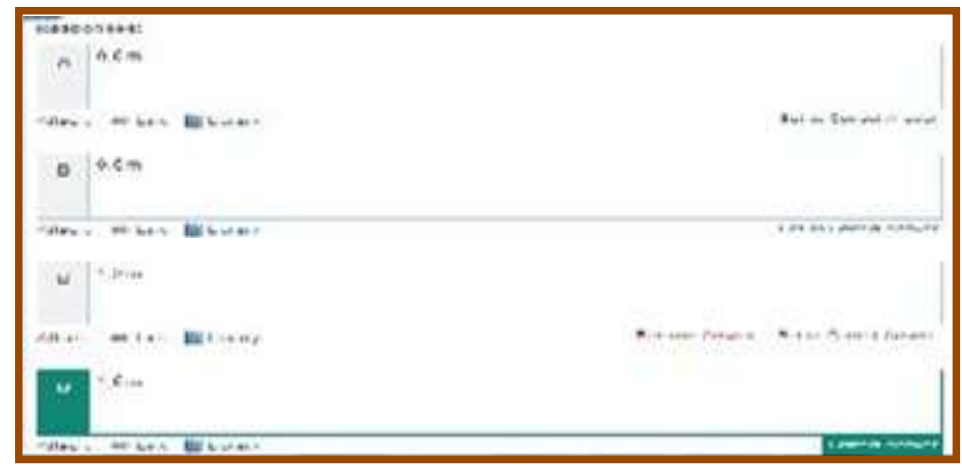

Untuk quiz multiple choice, pada tampilan Edmodo akan muncul pengaturan seperti gambar dibawah ini:

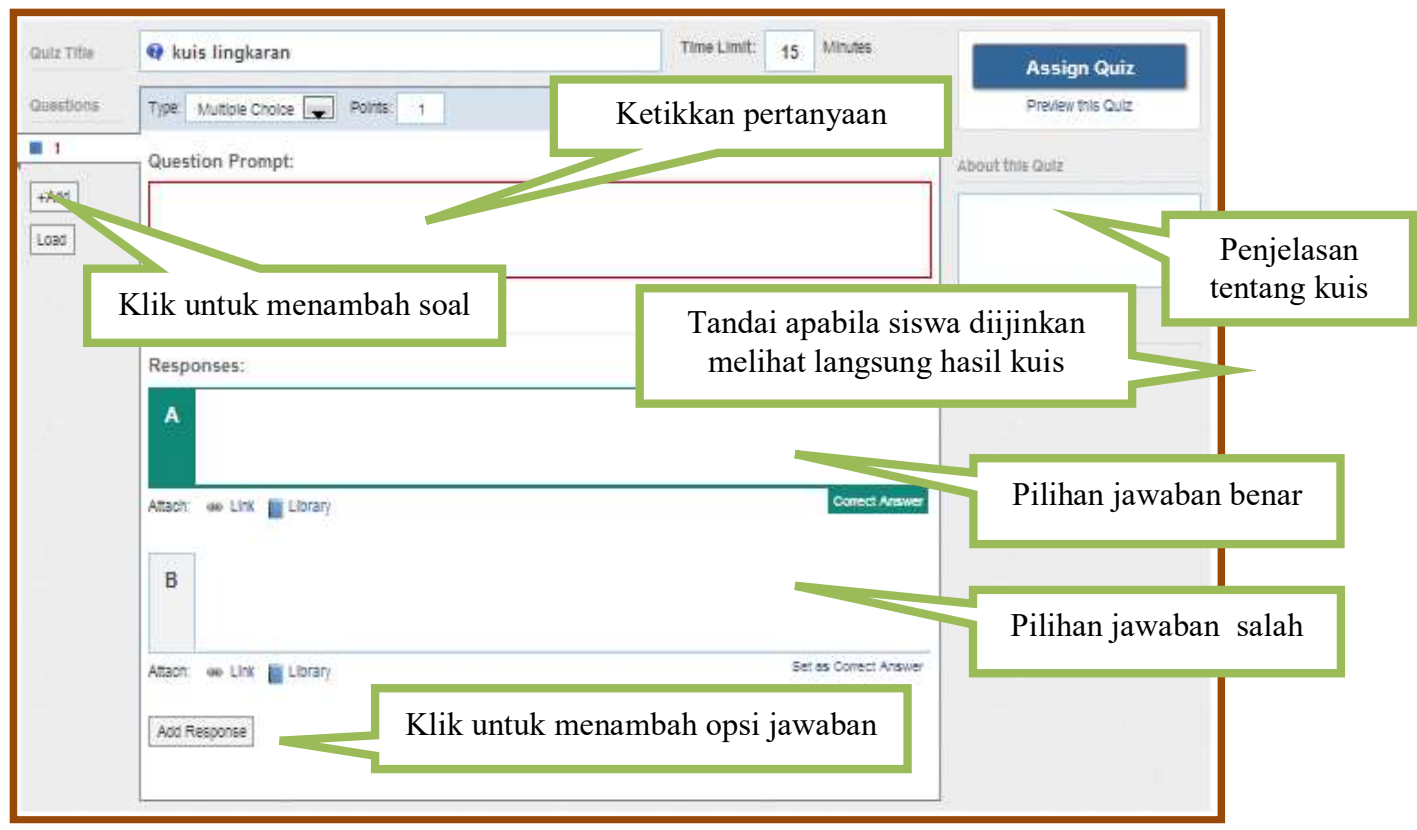

https://ojs.stkippgri-lubuklinggau.ac.id/index.php/JPM 
JURNAL CEMERLANG: Pengabdian pada Masyarakat ISSN 2654-4741

Vol. 1, No. 1, 2018, $71-89$

DOI: https://doi.org/10.31540/jpm.v1i1.160

- True-False Quiz

Sama halnya dengn multiple choice quiz, guru hanya perlu mengubah tipe quiz yang akan diberikan. Kemudian gurubisa membuat pertanyaan benar-salah. Pada Edmodo, telah disediakan pilihan jawaban untuk yang benar dan yang salah.

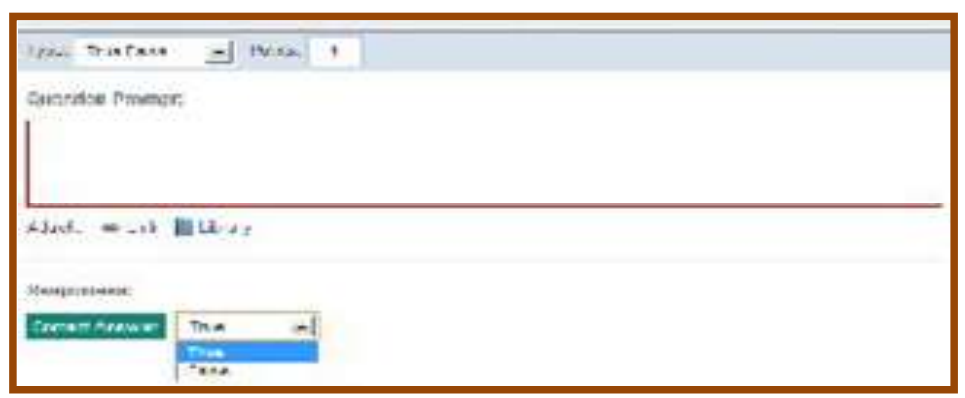

- Short Answer Quiz

Untuk pertanyaan padashort answer quiz berupa suatu kalimat tanya yang bisa dijawab secara singkat, berupa kata, frase, nama, tempat, nama tokoh, lambang, dll.

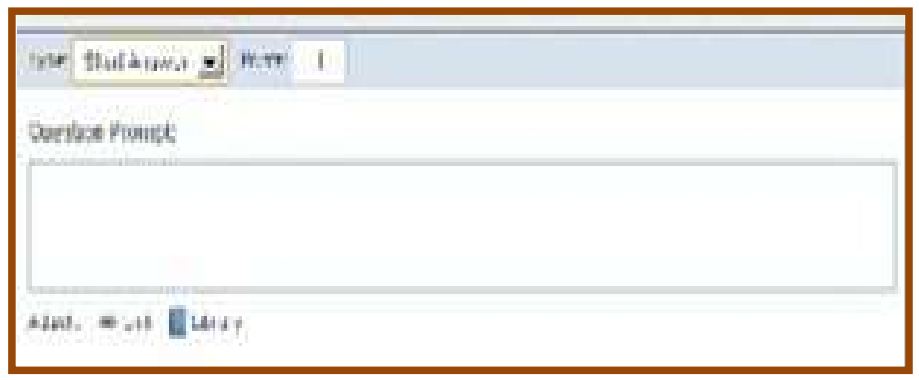

- Fill in the Blank Quiz

Pertanyaan bentuk melengkapi dikemukakan dalam pernyataan yang belum lengkap.

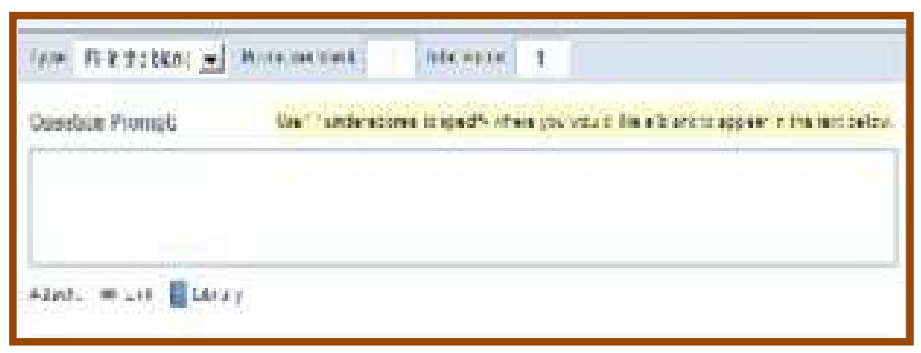

https://ojs.stkippgri-lubuklinggau.ac.id/index.php/JPM 
JURNAL CEMERLANG: Pengabdian pada Masyarakat ISSN 2654-4741

Vol. 1, No. 1, 2018, $71-89$

DOI: https://doi.org/10.31540/jpm.v1i1.160

f. Membuat penilaian

Pada karakteristik penilaian, guru dapat secara langsung memberi nilai pada tugas/latihan yang telah disposting di Edmodo sebelumnya.

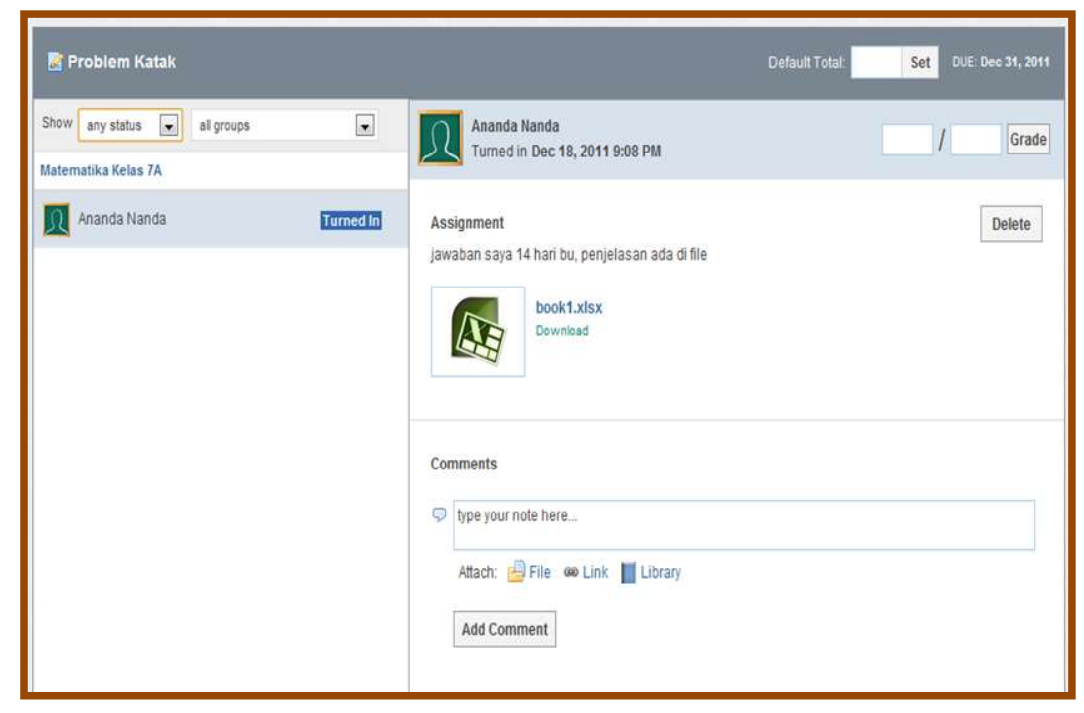

g. Mengakses kode/sandi untuk orang tua siswa

Orang tua dari setiap siswa bisa bergabung pada akun Edmodo untuk memonitoring prestasi dan hasil belajar putra-putri mereka.Guru harus menentukan kode/sandi untuk orang tua siswa dan kemudian membagikannya.Akses kode/sandi untuk orang tua siswa bisa didapatkan dengan memilih nama kelas, kemudian pilih Parent Code Spreadsheet.

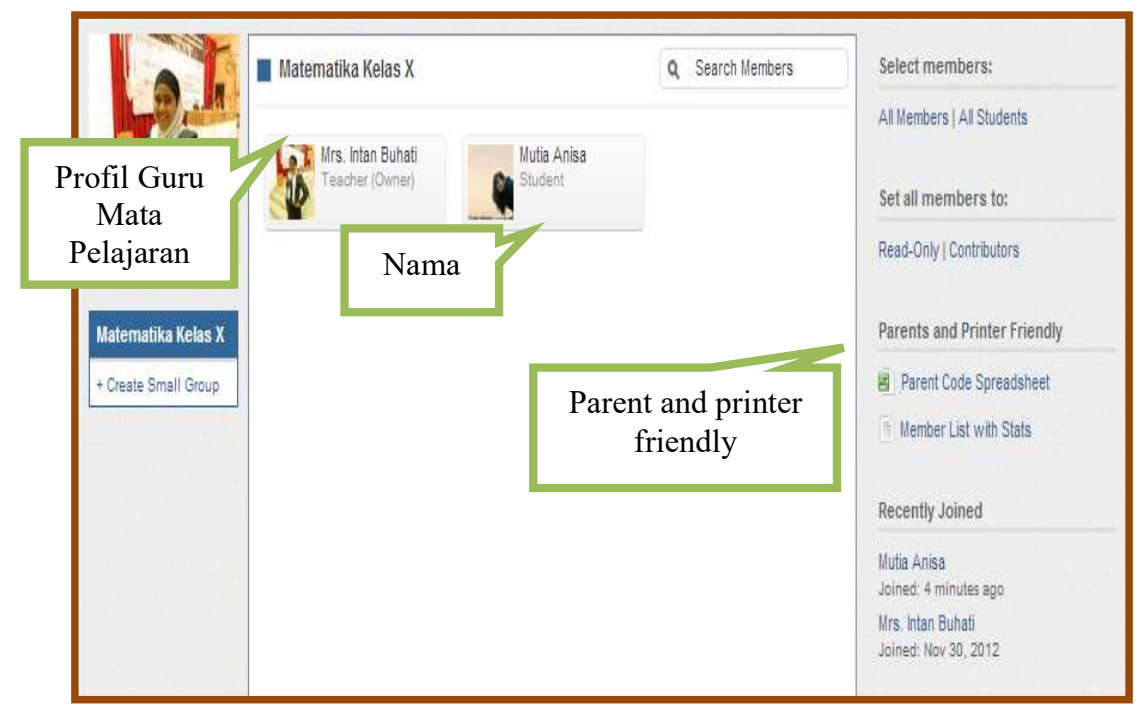

https://ojs.stkippgri-lubuklinggau.ac.id/index.php/JPM 
JURNAL CEMERLANG: Pengabdian pada Masyarakat ISSN 2654-4741

Vol. 1, No. 1, 2018, $71-89$

DOI: https://doi.org/10.31540/jpm.v1i1.160

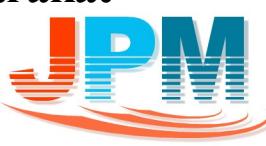

Kita akan diminta mendownload suatu file excel yang terdiri dari dua kolom, yakni kolom nama seluruh siswa dan kolom kode orang tua.

\begin{tabular}{|c|c|c|c|c|}
\hline \multicolumn{5}{|c|}{ parent-codes-matematika_kelas__. Microsoft Excel } \\
\hline 1 & A & B & C & D \\
\hline 1 & \multicolumn{3}{|c|}{ Student, Parent Code } & \\
\hline 2 & \multicolumn{3}{|c|}{ anisa, mutia,"g08maw" } & \\
\hline 3 & & & & \\
\hline 4 & & & & \\
\hline
\end{tabular}

Kita dapat membagikan kode/sandiyang telah dibuat kepada orang tua siswa yang tergabung dalam akun Edmodo. Kemudian, jika orang tua siswa ingin bergabung, maka pada awal halaman pilih Parent Sign-Up.

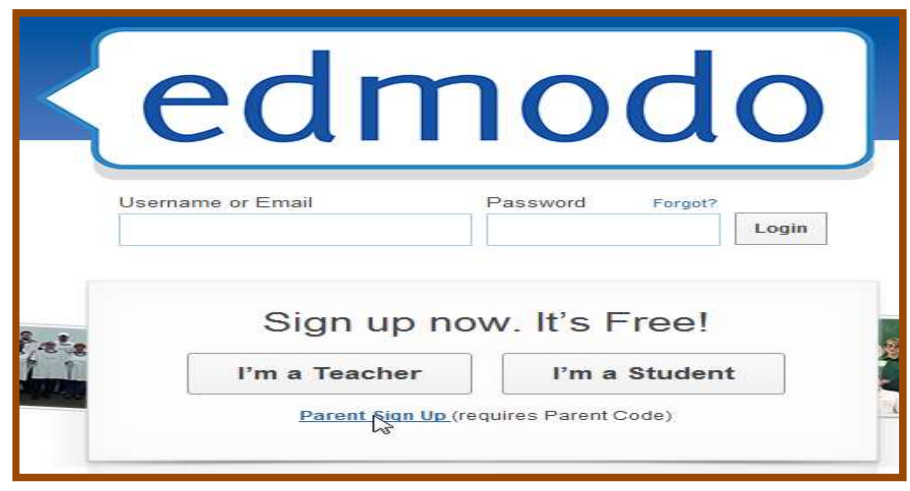

Kemudian muncul halaman isian yang harus dilengkapi,

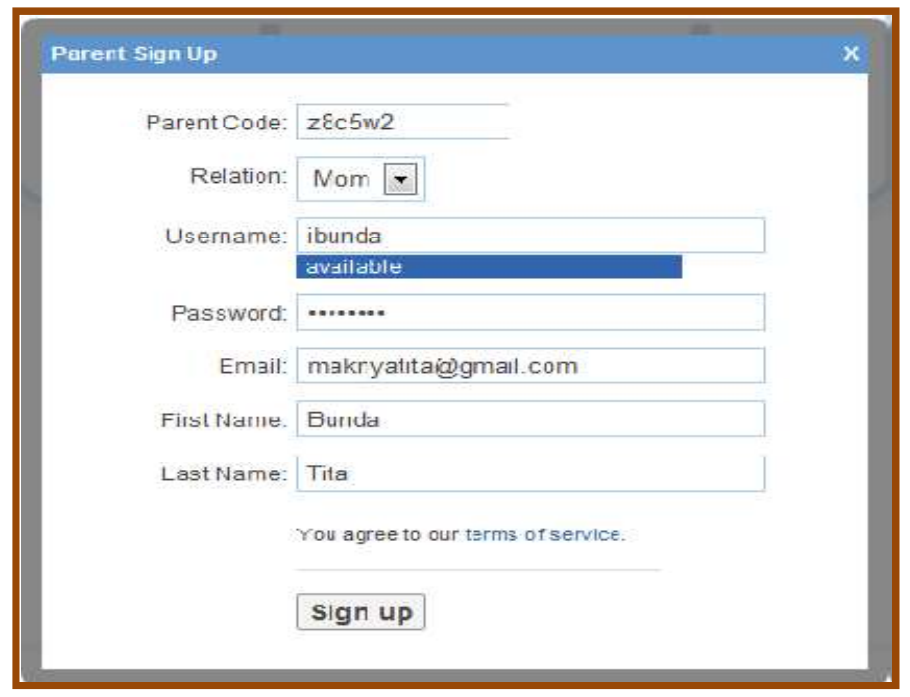

https://ojs.stkippgri-lubuklinggau.ac.id/index.php/JPM 


\section{JURNAL CEMERLANG: Pengabdian pada Masyarakat}

ISSN 2654-4741

Vol. 1, No. 1, 2018, $71-89$

DOI: https://doi.org/10.31540/jpm.v1i1.160

Pada tahap evaluasi kegiatan yang dilakukan adalah tanya jawab mengenai implementasi kegiatan pelatihan media social Edmodo yang telah dilaksanakan.

Dengan adanya kegiatan pelatihan ini memberikan suatu manfaat bagi guru khususnya di SMP Tamansiswa Palembang dalam mengembangkan suatu media pembelajaran. Edmodo bisa digunakan sebagai media bagi guru dan siswa untuk menerapkan metode belajar yang lebih menyenangkan serta memudahkan komunikasi antara guru dan siswa sehingga menjadikan suatu hubungan yang lebih deka tantara guru dan siswa. Dengan menggunakan Edmodo, memudahkan bagi guru untuk melakukan pembelajaran kapan saja. Pembelajaran bisa dilakukan di luar kelas tanpa tatap muka dan di luar jam pelajaran. Jadi dengan diadakan pelatihan ini guru bisa memberikan catatan pembelajaran, latihan soal, dan tugas kepada siswa serta bisa juga membagikannya ke ruang publik. Guru juga bisa menjadikan Edmodo sebagai media untuk memberikan soal ujian, tugas, dan kuis kepada siswa. Selain itu, guru bisa memanfaatkan smartphone/gadget untuk mengakses Edmodo tanpa perlu menggunakan computer. Sehingga guru dan siswa bisa mengakses Edmodo kapan saja dan dimana saja yang terdapat akses internet, karena guru dan siswa selalu menggunakan smartphone/gadget untuk kebutuhan komunikasi.

Kegiatan pengabdian masyarakat yang dilaksanakan telah berlangsung dengan baik, dapat terlihat dari animo dan semangat guru untuk mengikuti kegiatan ini, terbukti dengan kehadiran guru untuk mengikuti kegiatan yang mencapai $100 \%$. Hal ini menunjukkan bahwa para guru menyambut positif kegiatan pelatihan yang telah dilaksanakan. Apalagi media sosial Edmodo yang diperkenalkan merupakan hal baru bagi mereka. Kepala sekolah jugamenyambut antusias terkait pelaksanaan kegiatan ini. Kepala sekolah dan guru-guru bahkan berharap agar kegiatan ini bisa dilakukan secara berkesinambungan. 
JURNAL CEMERLANG: Pengabdian pada Masyarakat ISSN 2654-4741

Vol. 1, No. 1, 2018, $71-89$

DOI: https://doi.org/10.31540/jpm.v1i1.160

Kegiatan Pelatihan Media Sosial Edmodo:
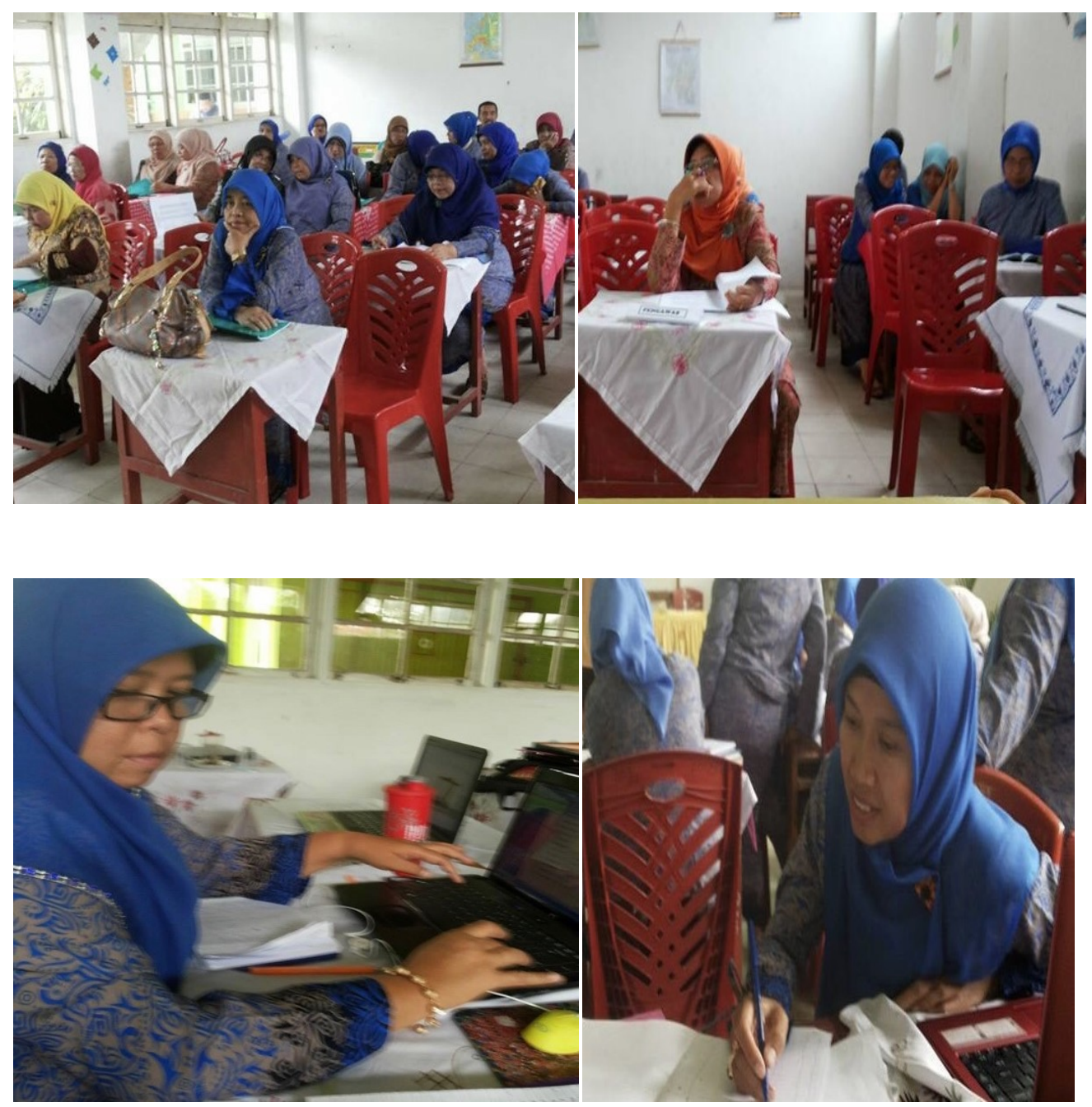

Ada sebagian guru yang tidak membawa laptop/notebook, jadi mereka menggunakan smartphone/gadget untuk melakukan pelatihan pembuatan akun media sosial Edmodo. Dengan telah dilakukannya kegiatan ini, sehingga guru bisa memanfaatkan Edmodo sebagai media dalam proses pembelajaran. 


\section{JURNAL CEMERLANG: Pengabdian pada Masyarakat}

ISSN 2654-4741

Vol. 1, No. 1, 2018, $71-89$

DOI: https://doi.org/10.31540/jpm.v1i1.160

\section{SIMPULAN}

Dari keseluruhan pelaksanaan pelatihan terlihat hasil yang baik dengan simpulan:

1. Peserta sudah dapat membuat akun Edmodo yang nantinya bisa digunakan dan diterapkan dalam proses pembelajaran di sekolah serta sudah bisa menggunakan fitur-fitur yang ada pada Edmodo.

2. Peserta memiliki media pembelajaran Edmodo sebagai salah satu media pembelajaran pada setiap bidang ilmu yang dimiliki oleh pesertadalam proses pembelajaran di sekolah.

3. Dengan adanya fitur ini, pesertabisa menggunakannya sebagai sarana berbagi ilmu dan pengetahuan serta mempermudah dalam berkomunikasi dengan siswa.

\section{DAFTAR PUSTAKA}

Ekawati, Estina \& Tamimuddin, M. (2011) Ekspektasi Pemanfaatan Online Social Network dalam Pembelajaran. Jurnal Edukasi Matematika, Vol 2 270-277.

Kurniasih, Ia. (2016). Apa itu Edmodo. (https://iakurniasih.wordpress.com/ 2016/04/08/apa-itu-edmodo/ diakses pada tanggal 12 Agustus 2018).

Munir. (2010). Kurikulum Berbasis Teknologi dan Komunikasi. Alfabeta : Bandung.

Pitoy, Yani Pieter. (2012). Making Mathematics Learning Excited: New Hope, New Spirit with Edmodo. (http://p4tkmatematika.org/ diakses pada tanggal 12 Agustus 2018).

Reza, Jeko Iqbal. (2017). Indonesia Negara ke-4 dengan Pengguna Facebook Teraktif di Dunia. (https://www.liputan6.com/tekno/read/2926217/ indonesianegara-ke-4-dengan-pengguna-facebook-teraktif-di-dunia diakses pada tanggal 20 Juli 2018).

Rustian, Rafi Saumi. (2012). Apa itu Sosial Media. (http://unpas.ac.id/pages/apaitu-sosial-media/ diakses pada tanggal 12 Agustus 2018). 
JURNAL CEMERLANG: Pengabdian pada Masyarakat ISSN 2654-4741

Vol. 1, No. 1, 2018, $71-89$

DOI: https://doi.org/10.31540/jpm.v1i1.160

Septania, Rizky Chandra. (2018). Indonesia, Pengguna Facebook ke-4 di Dunia. (https://tekno.kompas.com/read/2018/03/02/08181617/indonesia-penggunafacebook-terbanyak-ke-4-di-dunia diakses pada tanggal 20 Juli 2018).

Supriatna, Andi. (2013). Pengertian Jaringan Komputer (Network Computer). (http://andybroo.blogspot.com/2013/09/pengertian-jaringan-komputernetwork.html diakses pada tanggal 12 Agustus 2018).

Tea, Romel. (2014). Media Sosial: Pengertian, Karakteristik, dan Jenis. (https://www.romelteamedia.com/2014/04/media-sosial-pengertian karakteristik . html diakses pada tanggal 20 Juli 2018).

Zakaria, Muhammad. (2018). Tentang Edmodo: Pengertian, Manfaat, dan Fiturfiturnya yang Wajib Anda Ketahui. (https://www.nesabamedia.com/pengertianmanfaat-dan-fitur-edmodo/ diakses tanggal 12 Agustus 2018).

https://ojs.stkippgri-lubuklinggau.ac.id/index.php/JPM 